\title{
A kétszáz éves álmodó
}

\section{(Utószó)}

Vörösmarty nem írt verset Kolozsvárhoz, tudomásunk szerint nem ihlette a város vagy lakossága írásra. Mégis: a város, ahol félnapot töltött, és ahol fáklyás zenével köszöntötte valaha az ifjúság, őrzi régi vendége emlékét. Nem annyira a rövid kolozsvári szállást és az ahhoz kapcsolódó életmozzanatokat, hanem a Csongor és Tündében, a Szózatban, a könyv- és könyvtárversekben ránk hagyományozódott teremtett alakokat és emlékezetes fantáziaképeket, markáns ritmust, mély lélegzetnyi mondatot, szöveghangulatot.

A város? Az olvasók.

Azok pontosabban, akik nem rettegnek az itt-ott már szónokiasnak tủnő mondatok ívétől, a kalandos - gyakorta verses - történetektől; azok, akik szívesen ízlelgetik a találó sorokat ma is.

A konferencia és a kötet címe nem szorul mentegetésre. A szöveggé lett fantáziaképek, a szöveges alkotás müvészi merészsége, az ötlettelen élet elutasítása az álom. Kölcsey mondta: ,a költő a hétköznapok nyomvasztó világából kikapva él”; a költő Vörösmartyról és a Vörösmarty-szövegek életéről szólnak az itt olvasható tanulmányok.

Vörösmarty Mihály színházi szerző szeretett volna lenni legszívesebben. Drámakísérletei közül a Csongor és Tünde jelent ma legtöbbször jó értelemben vett kihívást; de $A$ fátyol titkait is játsszák néha, néhol: például 1999 december óta Kolozsváron. Mégis kínálkozott a kérdés: a kritikai kiadásban már három évtizede olvasható klasszikus életmü mennyire érdekes ma; van-e mondanivalónk a szövegkritikai „helyretétel” akadémikus gesztusa után a költőről; változott-e mostanában a müvek rangsora, és ha igen, kinek a számára, szükség van-e helyesbítésekre a szöveghagyománnyal kapcsolatban?

Álmodónk, Vörösmarty címmel rendeztünk a Magyar Irodalomtudományi Tanszéken konferenciát a költő emlékére. A témaajánlatok együttese arra utalt, mi foglalkoztatja a mai kutatót - és milyen mai problémának az elmondása egyszerübb Vörösmarty müveinek, személyes döntéseinek értelmezése által. A konferencia tudományos és baráti alkalmát fel is kínáltuk az olvasói-értelmezői szabadság jegyében valami Vörösmartyval (és főleg mủvével) kapcsolatban álló tudományos mondanivaló nyilvánossá tételére.

Meghívottaink éltek ezzel a szabadsággal.

A viták résztvevői is. Az egyik kerekasztal-megbeszélés volt, a Csongor és Tündéről. Kerényi Ferenc vállalta a házigazda szerepét; Gyapay László, Bodó A. Ottó, a kolozsvári diákság „,színeiben” Székely Melinda volt a vita meghívottja; de csakhamar kiderült, a közönség soraiban sokan szeretik, és főleg ismerik - a stílusfordulatok részleteiig terjedően - az Árgyélus-mesének ezt a romantikus változatát... A Csongor és Tünde megközelítésére önálló dolgozatban vállalkozott a debreceni 
Kossuth Lajos Tudományegyetem hallgatója, Lajosi Krisztina, majd Török Ervin, kolozsvári diák.

A másik vita a Vörösmarty-szövegértelmezések egyéni megoldásaira vonatkozott.

Nem kívánunk elhamarkodottan általánosítani, de bízvást állíthatjuk: a Vörösmarty-szövegkincs gondolkodtató és eleven; hatásának feltárására pedig még egy konferencia is csak ötleteket, irányokat adhat.

A kolozsvári születesnap-előzetes 1999. december 10-11-én alkalmat teremtett új Vörösmarty-olvasatok bemutatására. Az ígért és az elkészült tanulmányok közti különbség - a transzcendentális rés! - azt jelzi, hogy a Vörösmarty-életmű ellenáll a hirtelen olvasó- és értelmező kedvnek: az ilyen típusú irodalmi olvasmányhoz hozzá kell készülni, elidőzni fölötte, mint a sirály teszi a vizek fölött.

Lámcsak: olvasnunk kell (verses) történeteit. Zentai Mária szerint a fantázia következetessége az olvasás kérlelhetetlenségét vonhatja maga után: az eredmény sajátos jelentésvilág, ami nemcsak a magyar nemzeti problematikának ad új színt, hanem Vörösmarty-olvasásunkat is befolyásolja. Szajbély Mihály Herder-előítéletek lebontásán fáradozik értekezésében. Valóban: hatásokról vagy véletlen egyezésekről van szó; például a Hábador esetében tudatos Shakespeare-imitációról, vagy nem is tudatosult olvasmány-reminiszcenciáról? (Homonna hölgye) Az olvasó költő emlékét leginkább Horváth Andor tanulmánya idézte ebben a sorozatban; a korabeli Európa izgalmas eszméinek és a kései Vörösmarty-versek filozofikumának egybevetésével. Remény és emlékezet egybejátszásáról Debreczeni Attila szólt. Fried istván és Melczer Tibor értékes hozzászólása postán érkezett.

Szabó Levente a nemzeti identitás problémáját kereste Gyulai Pál Vörösmartyértelmezéseiben.

De nézzük a kötet jelenvalóságát.

Amedeo Di Francesco összefoglalta az itáliai Vörösmarty-fordítások történetét.

Gaal György új adatokkal gazdagítja az utazó Vörösmartyval kapcsolatos ismereteinket; a rövid kolozsvári tartózkodás mellé írja a költő partiumi irodalmi „kalandozásának" fordulatos történetét. Pávai Gyula a költő aradi barátairól, követőiről értekezve a centrum és a „periféria” hasznos történelmi kapcsolatára hívja fel a figyelmet.

Antal Árpád arra emlékeztet, hogy a klasszikusok közvetítése sem volt problémamentes a XX. század túlpolitizált oktatási rendjében; hogy a nemzeti imádság szerzője csak a hivatalos eszmerendszer valamelyik jelszavával egybehangzóan válhatott tananyaggá vagy új kiadvánnyá.

A Tudományos Diákkonferencián meghirdetett témában (Vörösmarty dramaturgiája) három dolgozat született, szerzőik meghívást kaptak a konferenciára is. Székely Melinda Vörösmarty drámai költői koncepcióját közelítette meg; Bánházi Emőke A fátyol titkai komikumát értelmezte; Antal Ildikó a „marivaudage” bohózati elemeit nyomozta Vörösmarty álarcos darabjaiban.

A romániai vasutassztrájk veszélyeztette a konferencia sikerét. Több előadó ezért nem is tudott eljönni a rendezvényre, de néhányuk tanulmányát legalább ez a születésnapi ajándékkötet tartalmazza.

A konferencia munkálatainak két napját Kerényi Ferencnek a Vörösmarty-kutatás mai állapotára vonatkozó szavai zárták. 
A konferencia első napján este a rendezvény közönsége megkoszorúzta a költő fötéri emléktábláját. Három nappal később Kányádi Sándor jelenlétében a Vörösmarty-vándorkiállítás felavatására került sor, a Petőfi Irodalmi Múzeum által összeállított anyagból. Ez a kiállítás hat hét után Szatmárra „utazott tovább”. A költőt magát ittmarasztaltuk a tanszéken; márciusban Vörösmarty-esten versben, zenében találkoztak vele az egyetemi diákok. Örömmel mondjuk, hogy Székesfehérvár és Varsó mellett Kolozsváron is otthonra lelt ebben az évben a Szózat szerzője; ismerősünkké lett a gyakori találkozás révén.

Kedves olvasó! Ez a konferenciával előbűvölt kis kötet önmagában is jó szívvel ajánlott gyüjtemény elmélkedésekből, közleményekből. Legjobb mégis együtt olvasgatni ezeket a Vörösmarty-szövegekkel.

Akár így, akár úgy: érvényes álmokat kívánunk a költővel, születésnapján.

Kolozsvár 2000. dec. 1.

Egyed Emese 